\title{
Does Peacekeeping Keep Peace? International Intervention and the Duration of Peace After Civil War
}

\author{
Virginia Page Fortna \\ Columbia University
}

\begin{abstract}
This article examines international interventions in the aftermath of civil wars to see whether peace lasts longer when peacekeepers are present than when they are absent. Because peacekeeping is not applied to cases at random, I first address the question of where international personnel tend to be deployed. I then attempt to control for factors that might affect both the likelihood of peacekeepers being sent and the ease or difficulty of maintaining peace so as to avoid spurious findings. I find, in a nutshell, that peacekeeping after civil wars does indeed make an important contribution to the stability of peace.
\end{abstract}

Does peacekeeping work? Do international interventions to help maintain peace in the aftermath of civil war actually contribute to more stable peace? Since the end of the Cold War the international community and the UN have moved beyond "traditional peacekeeping" between states and have become much more involved in civil conflicts, monitoring and often managing or administering various aspects of the transition to peace within states.

Scholars and practitioners of peacekeeping have debated the merits of the new wave of more "robust" and complex forms of peacekeeping and peace enforcement developed after the Cold War, and even over the effectiveness of more traditional forms of peacekeeping (Tharoor, 1995/96; Luttwak, 1999). However, this debate is hampered by lack of rigorous testing of the effectiveness of these interventions by the international community. We do not have a very good idea of whether they really work.

Opponents of peacekeeping often point to dramatic failures that dominate news coverage of peacekeeping without acknowledging the success stories that make less exciting news. Proponents are also guilty of selection bias, however. The vast literature on peacekeeping compares cases and missions, but generally examines only cases in which the international community intervenes, not cases in which belligerents are left to their own devices. Surprisingly, very little work has been

\footnotetext{
Author's note: This project was made possible by a grant from the Carnegie Corporation and a Visiting Scholarship at the American Academy of Arts and Sciences, for which the author is extremely grateful. For comments and suggestions, she also thanks Bob Art, Allison Bailey, Michael Barnett, Amitabh Dubey, Nisha Fazal, Erik Gartzke, Lise Howard, Bob Jervis, Kim Marten, Dan Reiter, Nicholas Sambanis, Jack Snyder, Monica Toft, and Barb Walter. Earlier versions of this paper were presented at the 2002 annual meetings of the International Studies Association, Harvard's Olin Institute, Yale's international relations speaker series, PNCIS at the University of Washington, CIS at Princeton, and the Political Science Department at Emory University.
} 
done to examine empirically whether peace is more likely to last in cases where peacekeepers are present than when they are absent. ${ }^{1}$

Moreover, the few studies that do address this empirical question, at least in passing, come to contradictory findings. In their study of peacebuilding in civil wars since World War II, Doyle and Sambanis (2000) "find that multilateral, United Nations peace operations make a positive difference." In particular, they find strong evidence that multidimensional peacekeeping, i.e, "missions with extensive civilian functions, including economic reconstruction, institutional reform, and election oversight" significantly improve the chances of peacebuilding success (measured two years after the end of the war). They find weaker evidence that observer missions and enforcement missions improve the chances for peace, but, surprisingly, that traditional peacekeeping has no effect on the chances for peacebuilding success. Hartzell, Hoddie, and Rothchild (2001) find that third-party involvement (which includes peacekeeping missions) significantly and substantially increases the duration of peace. However, in a study using Doyle and Sambanis's data set but more sophisticated statistical techniques, Amitabh Dubey (2002) finds, inter alia, that third-party peacekeeping interventions, including those by the UN, have no significant effect on the duration of peace. Of the three studies that examine whether peace lasts longer when peacekeepers are present than when they are absent, one finds that it does, one that it does not, and one finds that only some kinds of peacekeeping are effective. ${ }^{2}$ From the existing studies, it is not at all clear whether peacekeeping works. A closer look is clearly needed.

This paper examines peacekeeping in the aftermath of civil wars. I test the hypothesis that peacekeeping contributes to more durable peace, and the null hypothesis that it does not make peace significantly more likely to last. ${ }^{3}$ I look at both UN peacekeeping and peacekeeping by other organizations or ad hoc groups of states, and explore the effects of different types of peacekeeping: observer missions, traditional peacekeeping, multidimensional peacekeeping, and peace enforcement. Observer missions are typically small in size and involve unarmed monitors. Traditional peacekeeping missions are somewhat larger and involve lightly armed military units (often in addition to observers). They are usually authorized to use force only in self-defense. Multidimensional peacekeeping missions supplement traditional peacekeeping forces with large civilian components to monitor elections, train or monitor police, monitor human rights, and sometimes temporarily to administer the country. All three of these types of mission are based on the consent of the parties and are authorized under Chapter VI of the UN Charter. Enforcement missions are authorized under Chapter VII, and do not necessarily require the consent of the belligerents. ${ }^{4}$ Their forces are generally better armed and larger, mandated to impose peace by force. This study surveys civil conflicts in the period since World War II, but it focuses in particular on peacekeeping since the end of the Cold War. The role played by outsiders in civil wars changed drastically with the end of the Cold War. Between 1946 and 1988, the

\footnotetext{
${ }^{1}$ Case studies of peacekeeping's effect in particular missions either do not address this issue or rely, usually implicitly, on counterfactual assessments. See, for example, Dawson (1994), Doyle (1995), and Holiday and Stanley (1992). For a good example of comparative work on peacekeeping success and failure that takes peacekeeping missions as the universe of cases, see Howard (2001). See also Durch (1996) and Hampson (1996).

${ }^{2}$ These different conclusions are likely driven by differences in case selection (Doyle and Sambanis and Dubey examine all civil wars, Hartzell et al. only those that end with a negotiated settlement), or by differences in the dependent variable (the duration of peace for Dubey and Hartzell et al.; for Doyle and Sambanis, whether peace is holding at an arbitrary cut-off point of two years).

${ }^{3}$ Note that I define peace merely as the absence of war, not as some sort of negotiated settlement of the issues over which the war was fought. In other words, I am interested in the duration of "negative" peace rather than "positive" peace.

${ }^{4}$ Because they represented a development not envisioned in the Charter, consent-based missions are sometimes referred to as "Chapter six-and-a-half." More robust missions short of enforcement have been dubbed "Chapter sixand-three-quarters" and are also sometimes referred to as "gray area" peacekeeping.
} 
international community was generally not in the business of keeping peace between belligerents within states. The UN and others occasionally intervened in civil wars during this time period (in the Congo, Lebanon, and Cyprus ${ }^{5}$ ), but these missions were intended to contain civil conflicts that might otherwise draw in the great powers and/or to assist decolonization, not necessarily to keep peace between civil war belligerents themselves.

Starting with the peacekeeping mission in Namibia in 1989 (UNTAG), however, the international community has attempted peacekeeping in many more civil wars. The practice of peacekeeping has evolved accordingly, now generally involving much more extensive civilian components: electoral observation, police monitoring and training, and civilian administration. Since the Cold War, the primary purpose of peacekeeping has been to prevent the resumption of civil conflict. It is therefore likely that the relationship between peacekeeping and the duration of peace changed with the end of the Cold War. ${ }^{6}$

\section{A First Glance, and Why a Second Is Needed}

As noted above, to know whether peacekeeping makes a difference we need to look at the aftermath of all civil wars, not just those in which peacekeepers were deployed. From such a look it is not at all self-evident that peacekeeping works. A first glance at civil wars and peacekeeping does not bode well for judgments about the effectiveness of the international community's attempts to maintain peace. Table 1 shows the bivariate relationship between peacekeeping and whether war resumes. ${ }^{7}$ The relationship is broken down in four ways: for all peacekeeping (top half), and for UN peacekeeping only (bottom); for the whole post-World War II period (left half) and only for the post-Cold War period (right).

Peacekeeping appears to make very little difference. Of the civil wars since 1944, there is another round of fighting between the same parties in about $42 \%$ when no peacekeepers were deployed, and in approximately $39 \%$ of those with peacekeeping. The numbers are even worse for UN peacekeeping, with peace slightly more likely to fail when UN peacekeepers are present than when they are absent. After the Cold War, the record of peacekeeping is slightly better, but in none of these cross tabulations is the difference between peacekeeping and no peacekeeping statistically significant. A breakdown by type of peacekeeping, in Table 2, suggests that observer missions and multidimensional peacekeeping may reduce the likelihood of another war, but that traditional peacekeeping and enforcement missions do not. ${ }^{8}$

But looks, especially first glances, can be deceiving. To begin with, these tables treat peace that falls apart many years down the line the same as peace that fails in a matter of months. The resumption of war in Rwanda in 1990 after 26 years of peace is considered just as much a failure as the renewed fighting in Rwanda in 1994 after less than a year of peace. ${ }^{9}$ This quick glance also does not take into

\footnotetext{
${ }^{5}$ Organizations other than the UN deployed peacekeepers in internal conflicts during the Cold War in Chad, the Dominican Republic, and Zimbabwe. In an interesting foreshadowing of the administrative tasks the UN would later take on in Cambodia, Kosovo, and East Timor, the UN Temporary Executive Authority was set up in West New Guinea in 1962-63 as the territory transferred from Dutch to Indonesian control. (On this mission, see Durch (1993), Chapter 17).

${ }^{6}$ Note that my reason for differentiating between the Cold War and the years since is not that I think civil wars have changed drastically. I agree with Kalyvas (2001) that recent internal conflicts are not fundamentally different (more brutal or irrational, more driven by greed than grievance, etc.) than older civil wars. It is peacekeeping that has changed with respect to civil wars, not the wars themselves.

${ }^{7}$ See below for a description of the data used in Table 1 .

${ }^{8}$ Distinctions among mission types are from Doyle and Sambanis (2000).

${ }^{9}$ Many studies of the stability of peace use an arbitrary time period (five years, say) to determine whether peace is stable. But peace often falters more than five years out. The peace reached in the Sudan in 1972 fell apart eleven years later in 1983. The resumption of the Israeli-Palestinian conflict in 2000 after the peace deal reached in 1993 is another example. A continuous measure of the duration of peace is thus preferable to an arbitrary time period.
} 
TABLE 1. Peacekeeping and the Resumption of War: A First Glance

\begin{tabular}{|c|c|c|c|c|c|c|}
\hline & \multicolumn{3}{|c|}{ Post-WWII } & \multicolumn{3}{|c|}{ Post-Cold War } \\
\hline & No More War & More War & Total & No More War & More War & Total \\
\hline \multirow[t]{2}{*}{ No Peacekeeping } & 43 & 31 & 74 & 12 & 9 & 21 \\
\hline & $58.11 \%$ & $41.89 \%$ & & $57.14 \%$ & $42.86 \%$ & \\
\hline \multirow[t]{2}{*}{ Peacekeeping } & 25 & 16 & 41 & 23 & 11 & 34 \\
\hline & $60.98 \%$ & $39.02 \%$ & & $67.65 \%$ & $32.35 \%$ & \\
\hline \multirow{5}{*}{ Total } & 68 & 47 & 115 & 35 & 20 & 55 \\
\hline & $59.13 \%$ & $40.87 \%$ & & $63.64 \%$ & $36.36 \%$ & \\
\hline & \multicolumn{3}{|c|}{$\operatorname{Pr}\left(\chi^{2}\right)=0.76$} & \multicolumn{3}{|c|}{$\operatorname{Pr}\left(\chi^{2}\right)=0.43$} \\
\hline & \multicolumn{3}{|c|}{ Post-WWII } & \multicolumn{3}{|c|}{ Post-Cold War } \\
\hline & No More War & More War & Total & No More War & More War & Total \\
\hline \multirow[t]{2}{*}{ No UN Peacekeeping } & 51 & 34 & 85 & 19 & 11 & 30 \\
\hline & $60.00 \%$ & $40.00 \%$ & & $63.33 \%$ & $36.67 \%$ & \\
\hline \multirow[t]{2}{*}{ UN Peacekeeping } & 17 & 13 & 30 & 16 & 9 & 25 \\
\hline & $56.67 \%$ & $43.33 \%$ & & $64.00 \%$ & $36.00 \%$ & \\
\hline \multirow[t]{3}{*}{ Total } & 68 & 47 & 115 & 35 & 20 & 55 \\
\hline & \multirow{2}{*}{\multicolumn{3}{|c|}{$\begin{array}{r}\operatorname{Pr}\left(\chi^{2}\right)=0.75 \\
40.81 \%\end{array}$}} & $63.64 \%$ & $36.36 \%$ & \\
\hline & & & & \multicolumn{3}{|c|}{$\operatorname{Pr}\left(\chi^{2}\right)=0.96$} \\
\hline
\end{tabular}

TABle 2. Types of Peacekeeping and the Resumption of War: A First Glance

\begin{tabular}{|c|c|c|c|c|c|c|}
\hline & \multicolumn{3}{|c|}{ Post-WWII } & \multicolumn{3}{|c|}{ Post-Cold War } \\
\hline & No More War & More War & Total & No More War & More War & Total \\
\hline \multirow[t]{2}{*}{ No Peacekeeping } & 43 & 31 & 74 & 12 & 9 & 21 \\
\hline & $58.11 \%$ & $41.89 \%$ & & $57.14 \%$ & $42.86 \%$ & \\
\hline \multirow[t]{2}{*}{ Observer Mission } & 6 & 2 & 8 & 6 & 1 & 7 \\
\hline & $75.00 \%$ & $25.00 \%$ & & $85.71 \%$ & $14.29 \%$ & \\
\hline \multirow[t]{2}{*}{ Traditional Peacekeeping } & 7 & 6 & 13 & 5 & 3 & 8 \\
\hline & $53.85 \%$ & $46.15 \%$ & & $62.5 \%$ & $37.5 \%$ & \\
\hline \multirow[t]{2}{*}{ Multidimensional Peacekeeping } & 5 & 2 & 7 & 5 & 2 & 7 \\
\hline & $71.43 \%$ & $28.57 \%$ & & $71.43 \%$ & $28.57 \%$ & \\
\hline \multirow[t]{2}{*}{ Peace Enforcement } & 7 & 6 & 13 & 7 & 5 & 12 \\
\hline & $53.85 \%$ & $46.15 \%$ & & $58.33 \%$ & $41.67 \%$ & \\
\hline \multirow[t]{3}{*}{ Total } & 68 & 47 & 115 & 35 & 20 & 55 \\
\hline & $59.13 \%$ & $40.87 \%$ & & $63.64 \%$ & $36.36 \%$ & \\
\hline & \multicolumn{3}{|c|}{$\operatorname{Pr}\left(\chi^{2}\right)=0.81$} & \multicolumn{3}{|c|}{$\operatorname{Pr}\left(\chi^{2}\right)=0.70$} \\
\hline
\end{tabular}

account the fact that our data are "censored." We know whether peace has lasted to date, but we do not know if it will continue to last in the future. Peace is holding for the time being in Cambodia, for example, and in Northern Ireland, but these conflicts may yet flare up anew. ${ }^{10}$ Both of these problems can be dealt with using duration models, such as those employed in the analysis below.

\footnotetext{
${ }^{10}$ This problem is highlighted by cases in which peace failed after the data set was compiled, such as in Israel/ Palestine and Sierra Leone. I have recoded these accordingly, but there is no guarantee that other cases will not fail in coming months or years.
} 
However, the most important problem with the quick glance provided in Tables 1 and 2 is that peacekeeping is not applied to cases of civil war at random like treatments in a laboratory experiment. If peacekeepers tend to deploy only to relatively easy cases, where peace is quite likely to last in any case, then looking just at whether peacekeepers were present and the duration of peace will lead us to overestimate any positive effect on peace. Almost as clichés, analysts of peacekeeping argue that the international community should deploy only "when there is peace to keep" and when the parties exhibit "political will" for peace. Such a policy would help the UN and the international community to avoid embarrassing failures, but if pushed too far, it will also ensure the irrelevance of peacekeeping. On the other hand, if as is quite plausible, peacekeepers tend to be sent where they are most needed, when peace would otherwise be difficult to keep, this first glance at the cases will underestimate the effectiveness of peacekeeping.

A closer look at the cases with respect to war outcomes suggests that the latter relationship might hold. Table 3 shows the post-Cold War cases as tabulated in the lower right portion of Table 1, identifying each case and whether or not the war ended in a victory for one side, as opposed to a military draw. As the number of victories (marked $\mathrm{V}$ ) in the upper half of the table indicates, UN peacekeepers tend not to be deployed when war ends with a decisive winner (the only exceptions are Haiti and Rwanda in 1994). If decisive victories tend to yield more stable peace, a hypothesis tested below, then this would help to account for peacekeeping's poor showing in Table 1. Of those cases that end with no clear winner, peace fails in half (8 of 16) of those without peacekeepers, while only about one-third (8 of 23) of those with peacekeepers experience another war.

War outcome is only one of many factors that might affect the duration of peace. To reach accurate assessments of the international community's effectiveness at maintaining peace, we need to be able to gauge the "degree of difficulty" of the various cases (Blechman, Durch, Eaton, and Stanley, 1997). And we need to know in what sorts of conflicts peacekeepers are likely to be dispatched. There have been a handful of studies examining the former question, and one (to my knowledge) on the second question.

What makes peace more or less likely to endure after civil wars? As noted above, peace is thought to be harder to maintain when war ends in a stalemate or compromise settlement than if one side achieves a military victory. Indecisive military outcomes leave all sides capable of resuming the fight, and no one fully satisfied with the terms of the peace. Wars that end in a draw also leave greater uncertainty about who would win another round of fighting. ${ }^{11}$ That peace is more stable after decisive military victories than after wars that end in a tie is perhaps the most consistent finding of the literature on the durability of peace after both civil and interstate conflicts (Maoz, 1984; Kozhemiakin, 1994; Licklider, 1995; Stinnett and Diehl, 2001; Dubey, 2002; Toft, 2003; Fortna, 2004). On the other hand, peace that is ushered in with a formal peace settlement may be more stable than an informal truce. Formal agreements entail a political commitment to peace that invokes audience costs, both internationally and domestically. ${ }^{12}$

Ethnic divisions within a state affect its probability of experiencing civil war in the first place (Collier and Hoeffler, 1999), and many have argued that identity conflicts are particularly intractable (Mearsheimer and Pape, 1993; Kaufmann, 1996). Peace might therefore be harder to keep in conflicts that pit different ethnic or religious groups against each other as compared to wars fought over ideology. There is conflicting evidence on this count. Both Licklider (1995)

\footnotetext{
${ }^{11}$ For an argument about how this uncertainty can lead to war, see Fearon (1995).

${ }^{12}$ For a similar argument on the costs of agreement and credible signaling, see Hoddie and Hartzell (2003).
} 
TABLE 3. Victory, UN Peacekeeping, and the Resumption of War: Post-Cold War

\begin{tabular}{|c|c|c|}
\hline & No More War & More War \\
\hline \multirow[t]{20}{*}{ No UN peacekeeping } & \multicolumn{2}{|l|}{ Sri Lanka (JVP II) 1989} \\
\hline & Romania 1989 & Sri Lanka (Tamil) 1987 \\
\hline & Iraq-Kurds 1991 & Somalia 1991 \\
\hline & Eritrea 1991 & Afghanistan 1992 \\
\hline & Iraq-Shiites 1994 & Liberia 1993 \\
\hline & Ethiopia-ideology $1991 \mathrm{~V}$ & Israel-Palestine 1993 \\
\hline & India-Sikh $1994 \quad \mathrm{~V}$ & Philippines-NPA 1993 \\
\hline & Bangladesh-CHT 1994 & Congo Brazzaville 1996 \\
\hline & Mexico $1994 \quad \mathrm{~V}$ & Russia-Chechnya 1996 \\
\hline & Azerbaijan 1994 & Philip.-MNLF/MILF 1996 \\
\hline & Yemen 1994 & Sierra Leone 1996 \\
\hline & Chad 1994 & Congo/Zaire 1997 \\
\hline & Northern Ireland 1994 & \\
\hline & Moldova $1994 \quad \mathrm{~V}$ & \\
\hline & Djibouti 1994 & \\
\hline & Mali 1995 & \\
\hline & Burma 1995 & \\
\hline & Papua New Guinea 1997 & \\
\hline & Cambodia 1998 & \\
\hline & $\mathrm{N}=19$ & $\mathrm{~N}=11$ \\
\hline \multirow[t]{17}{*}{ UN peacekeeping } & Namibia 1989 & \\
\hline & Nicaragua 1989 & Angola 1991 \\
\hline & Lebanon 1991 & Cambodia 1991 \\
\hline & Morocco/W. Sahara 1991 & Yugoslavia-Croatia 1992 \\
\hline & Mozambique 1992 & Georgia-Abkhazia 1993 \\
\hline & El Salvador 1992 & Rwanda 1993 \\
\hline & Georgia-Ossetia 1994 & Yugoslavia-Croatia 1994 \\
\hline & South Africa 1994 & Rwanda 1994 \\
\hline & Georgia-Abkhazia 1994 & Angola 1994 \\
\hline & Guatemala 1994 & Sierra Leone 1999 \\
\hline & Haiti 1994 & \\
\hline & Tajikistan 1994 & \\
\hline & Yugoslavia-Croatia 1995 & \\
\hline & Yugoslavia-Bosnia 1995 & \\
\hline & Liberia 1996 & \\
\hline & Central Africa 1997 & \\
\hline & $\mathrm{N}=16$ & $\mathrm{~N}=9$ \\
\hline
\end{tabular}

$\mathrm{V}=$ War ends in victory for one side.

and Doyle and Sambanis (2000) found identity wars to be more likely to resume than others, but Hartzell et al. (2001) and Dubey (2002) found no significant difference. $^{13}$

There are competing hypotheses about the relationship between the cost of war (in terms of lives lost) and the durability of peace. One line of reasoning suggests that more costly wars indicate intractable conflicts that are more likely to resume.

\footnotetext{
${ }^{13}$ On a related issue, Walter (2001) found that ethnic conflicts are no less likely to end in negotiated settlement (as opposed to being fought to the finish) than are other types of conflict. There does not appear to be a relationship between the ethnic heterogeneity of the country and the difficulty of maintaining peace (Doyle and Sambanis, 2000; Dubey, 2002). On ethnic divisions and the duration of war (as opposed to peace), see Elbadawi and Sambanis (2000), Fearon (2002), and Soderbom, Collier, and Hoeffler (2002).
} 
Similarly the higher the death toll, the harder it will be for the two sides to reconcile with those responsible for the deaths of loved ones (Doyle and Sambanis, 2000). On the other hand, if it is the cost of war that provides the incentive to cooperate, then we would expect peace to be easier to maintain after the most deadly wars (Hensel, 1994; Werner, 1999; Fortna, 2004). Empirical studies have found that civil wars with higher death tolls are more likely to resume than less deadly conflicts (Doyle and Sambanis, 2000; Dubey, 2002). ${ }^{14}$ On the other hand, a war weariness hypothesis would suggest that longer wars will be followed by more stable peace. ${ }^{15}$

Complicated wars involving many factions have been found to be harder to solve in a lasting way than wars with only two sides (Doyle and Sambanis, 2000). Walter (2004) argues that economic development affects the likelihood of a return to war because those who would fight assess the opportunity costs of rebellion. A number of studies have found that peace is harder to maintain in countries where a high level of economic dependence on natural resources means that there are easily "lootable" goods (diamonds or oil, for example) that can drive continued conflict (Collier and Hoeffler, 2000, 2002; Doyle and Sambanis, 2000; Elbadawi and Sambanis, 2001; Dubey, 2002). ${ }^{16}$ The level of democracy in the country may also affect the stability of peace (Hartzell et al., 2001; Dubey, 2002; Walter, 2004).

In sum, the existing literature on the duration of peace suggests that to assess accurately the effects of peacekeeping, we need take into account the military outcome of the war, whether a treaty was signed, whether it was an ethnic conflict, its cost and duration, how many factions were involved, levels of economic development, availability of easily "lootable" resources, and the country's level of democracy.

Gilligan and Stedman (2001) have examined where and when the United Nations tends to intervene. Their focus is on intervention during conflict, and on how quickly the international community responds to civil wars, but their study provides some insight into the selection issue of interest here. Most relevant for our purposes, they find that "one of the best predictors of UN intervention is the number of deaths in a conflict," and strong evidence that the UN is less likely to intervene in countries with large government armies (i.e., militarily strong states). They find no clear evidence that the UN is more likely to intervene when a treaty has been signed, though they attribute this non-finding in part to problems of multicollinearity. They find that democracy, the war aims of the rebels (i.e., whether or not the war was secessionist), primary commodity exports, and whether or not the country is a former colony of a permanent member of the UN Security Council make no difference to the likelihood of UN intervention. ${ }^{17}$

Their findings that peacekeepers are more likely after very deadly conflicts (which are more prone to recurrent warfare), but not in strong states (which may be at less risk) suggest that peacekeepers may select relatively difficult cases. In the empirical analysis below, I examine first where peacekeepers are most likely to be deployed. This examination is certainly not exhaustive; there are likely many other factors that influence decisions by the international community to intervene. I focus on factors that are also likely to affect the stability of peace, factors whose omission

\footnotetext{
${ }^{14}$ Interestingly, however, the relationship is the opposite in interstate wars, where higher deaths tolls are associated with more stable peace, all else equal (Fortna, 2004).

${ }^{15}$ Hartzell et al. (2001) found the duration of war to be positively correlated with the duration of peace after negotiated settlements, but Doyle and Sambanis (2000) found only weak support for this hypothesis, and Dubey (2002) found no significant relationship.

${ }^{16}$ Fearon and Laitin (2003) argue that while access to financial resources may affect the likelihood of war, measures of primary commodity exports do not capture this effect well because some commodities are much harder to loot than others (agricultural products as opposed to diamonds, for example).

17 They also find that the UN is more likely to respond quickly in Europe than in Africa, but more quickly in Africa than in Asia, and that the likelihood (or more precisely the hazard rate) of intervention increases as the war drags on.
} 
would bias our assessment of whether peacekeeping works. Second, I examine the effects of peacekeeping on the durability of peace, controlling as much as possible for factors that might affect the "degree of difficulty" of the case.

\section{The Data}

This article examines a data set consisting of 115 spells of peace (some of which are ongoing) in or after civil wars. The cases are listed in the Appendix. The data are adapted from the data set put together by Michael Doyle and Nicholas Sambanis (2000) (hereafter called D\&S). ${ }^{18}$ Their data cover civil wars that started after 1944 and ended, at least temporarily, before 1997. They define a civil war as an armed conflict that caused more than 1,000 battle deaths (total, rather than in a single year as in the Correlates of War definition); that represented a challenge to the sovereignty of an internationally recognized state; and occurred within the recognized boundary of that state; that involved the state as one of the principal combatants; and in which the rebels were able to mount an organized military opposition to the state and to inflict significant casualties on the state.

Ideally, to test the effects of peacekeeping on maintaining peace, we would want information on every cease-fire in every civil war. Unfortunately, given the messy nature of most civil wars and, frequently, their stop-and-start nature, a comprehensive accounting of cease-fires does not exist. One of the benefits of using Doyle and Sambanis's data is that they attempted to code significant peacebuilding attempts, even if those attempts did not ultimately succeed in ending the war. In a few cases, I have also added observations (e.g., in Rwanda and Angola) for cease-fires missed in their list. However, the data used here undoubtedly omit a number of short-lived cease-fires. Because we are more likely to notice (and there is more likely to be information on) such ill-fated cease-fires when peacekeepers are present, this omission should tend to bias the findings away from the conclusion that peacekeeping works. That is, the data more likely omit failures of peace without peacekeeping than with it, so that if we had more comprehensive data we would find the stabilizing effects of peacekeeping to be greater. ${ }^{19}$

Note that I am examining whether peace lasts, not whether it was achieved in the first place. I am not comparing wars in which peacekeepers were deployed during the fighting (such as Somalia) to other wars to see if peacekeepers affect whether the fighting stops, that is, whether they make peace, but rather, whether they keep peace.

The duration of peace, the main dependent variable of interest, is the time between the termination of fighting and the start of another war, if any, between the same parties. ${ }^{20}$ Note that peace is not coded as failing if there is another war in the same country between substantially different actors (Dubey, 2002). If no war has

\footnotetext{
18 There are now a number of lists and data sets of civil wars available. I use theirs in part because they draw on many of these to compile their own. These data were converted to a time-varying format by Amitabh Dubey, whom I thank for generously sharing his work, as well as for his consultation about numerous cases and coding decisions. I have followed both Dubey (2002) and Gilligan and Stedman (2001) in adapting the data somewhat. Data and data notes are available from the author upon request.

${ }^{19}$ Note that the data also exclude cease-fires that were agreed to, but that never went into effect even for a short period. This selection likely further skews the findings away from my own argument as peacekeepers usually require at least a tenuous cease-fire to deploy. While there are some cases of cease-fires agreed to but never implemented when peacekeepers are deployed, the vast majority of them take place with no international personnel present.

20 Technically, duration models treat the dependent variable as whether or not peace fails in a time period, given that peace has lasted up to that period. Cease-fire dates and the dates of renewed warfare were coded by Amitabh Dubey based on entries in Keesing's Record of World Events.
} 
resumed, the duration of peace is considered censored on December 31, 1999. Of the 115 cases, 47 , or just over $40 \%$, "fail" with the eruption of another war. ${ }^{21}$

Peacekeeping is both a dependent variable (for the first part of my analysis) and an independent variable (for the second part). It is coded using both dummy variables (any vs. none) and by category of peacekeeping mission (none, observer, traditional peacekeeping, multidimensional peacekeeping, peace enforcement). Separate variables capture UN missions only, non-UN missions only, and both combined. ${ }^{22}$ Peacekeeping is coded both as a time-constant and a time-varying covariate. The former notes the most extensive type of peacekeeping deployed for the case, while the latter records changes in mission type over time, and the termination of the mission. So, for example, in the time-varying version, Cambodia is coded as having a traditional peacekeeping mission at first, then a multidimensional peacekeeping mission starting in March 1992, and as having no peacekeeping after the withdrawal of UNTAC in September 1993. In the time-constant version, Cambodia is coded as having a multidimensional mission. When peacekeeping is analyzed as a dependent variable, I use the time-constant version. To judge the effects of peacekeeping, I use both versions (see below).

Of the 115 civil wars examined here, international personnel were sent to keep the peace after 41 (7 during the Cold War, and 34 since 1989). The UN sent missions in 30 cases, all but 5 after the Cold War, and states or organizations other than the UN sent missions in 23 cases, all but 2 since 1989 (twelve cases had both a $\mathrm{UN}$ and a non-UN mission).

Dummy variables based on the D\&S coding of the war's outcome capture whether the fighting ended with a victory by one side (victory), and whether a peace treaty was signed (treaty). Inclusion of these two variables allows us to see differences between these categories and wars that end with an informal truce or cease-fire. ${ }^{23} \mathrm{~A}$ further dummy variable (wartype) distinguishes ethnic, religious, and identity conflicts from ideological, revolutionary, or other wars. The cost of the war (logdead) is measured using the natural log of the number of people killed (both battle deaths and civilian deaths). The duration of the war (wardur) is measured in months. ${ }^{24} \mathrm{~A}$ dummy variable (faction) marks whether the war involved more than two factions. ${ }^{25}$ The level of development of the country is coded with a proxy based on per capita electricity consumption (develop), and "lootables" or natural resource dependence is measured using primary commodity exports as a percent of GDP (exp). Prior history of democracy is measured using the average Polity score over the five years before the war (gurrlag5), and the size of the government's army is recorded $($ garm $) .{ }^{26}$

One caveat should be noted. In the post-Cold War period there are only 55 cases. With many independent variables, this relatively small-N puts a large strain on the statistical models tested below. The findings should therefore be treated with a bit of

\footnotetext{
${ }^{21}$ The mean duration of peace in the data is 14 years from the date of the cease-fire to the date of another war or to the date of censoring. The shortest peace spells are 51 and 52 days, in Georgia-Abkhazia and Liberia, respectively, both in 1993. The longest is 52 years in Paraguay, where peace has held since 1947.

${ }^{22}$ In cases that saw both a UN and non-UN mission, the "all peacekeeping" variables denote the higher category mission. For example, in Central Africa there was a traditional peacekeeping mission of African troops, and the UN deployed a multidimensional mission, so the coding for the latter is used.

${ }^{23}$ As in most quantitative studies of civil war, D\&S do not distinguish between the military outcome (victory vs. stalemate) and the political outcome (settlement vs. none). This would be problematic for interstate wars, in which it is possible to have both a victory by one side and a settlement (e.g., after the Yom Kippur War), but is probably less so for civil wars. More problematic is the lack of distinction between the formality of an agreement, if there was one, and whether it was a cease-fire or a political settlement. That is, should a formally signed cease-fire be treated as an "informal truce" or a "peace treaty"? D\&S appear to include such cases in their "informal truce" category.

${ }^{24}$ Note that war duration is moderately correlated with war outcome-longer wars are less likely to end in victory (correlation is - 0.32), and more likely to end in a treaty $(0.37)$ - and with the cost of war $(0.26)$.

${ }^{25}$ The number of factions and the cost of war are also moderately correlated $(0.28)$.

${ }^{26}$ All of these codings are from D\&S.
} 
caution. However, the data cover all cases meeting the D\&S definition of armed conflict, not just a representative sample. This minimizes the inference problems normally associated with a small-N.

\section{Where Do Peacekeepers Get Sent?}

Table 4 shows the results of logistic regressions in which the dependent variable is whether any peacekeeping mission was deployed after a civil war. The first column presents the results for the entire period 1947-1999. Columns two, three, and four show the results in the post-Cold War period (1989-1999) for all peacekeeping, UN peacekeeping, and non-UN peacekeeping, respectively. ${ }^{27}$ Because the determinants of peacekeeping might be very different for different types of missions, Table 5 shows the results of a multinomial logistic regression for a trichotomous variable distinguishing consent-based peacekeeping and enforcement missions from cases of no peacekeeping. ${ }^{28}$ In both tables, negative coefficients indicate factors that make peacekeeping less likely, positive coefficients indicate variables that are associated with peacekeeping deployments. ${ }^{29}$

Not surprisingly, and as we saw in Table 3, wars that end with a victory by either the government or the rebels are very unlikely to see UN peacekeepers deployed. In fact, there are no multidimensional peacekeeping missions in cases of victory by one side, and other forms of peacekeeping are rare in such cases. (The exceptions are Congo in 1965, Haiti and Rwanda in 1994.) However, as the fourth column of Table 4 shows, this relationship does not hold for non-UN peacekeeping (which is if anything more likely after a clear victory). ${ }^{30}$ Nor is the relationship statistically significant for enforcement missions (there is substantial overlap here, almost half of the non-UN missions are enforcement missions). But as Table 5 makes clear, consent-based peacekeeping is much more likely after wars that end in a stalemate rather than a decisive victory for one side over the other. These stalemated cases are likely to be difficult cases in which to keep peace.

More surprising are the results for the treaty variable. If peacekeepers deployed where there was "peace to keep" or where the combatants had signaled their "political will" for peace by signing a treaty, we would expect this variable to have a positive effect, especially on consent-based missions. While there are no strong relationships in Table 4, Table 5 shows quite clearly that this is not the case. In fact Chapter VI peacekeeping is less likely when a formal peace treaty has been reached. Because of the way D\&S code these variables, both the victory and treaty dummy variables show the difference from wars that end in an "informal truce" (the omitted category in the victory/treaty/truce trichotomy). So while peacekeepers were deployed in over $60 \%$ of the cases that ended with a treaty, as compared with only $11 \%$ of those that ended with a victory, they were sent to over $78 \%$ of those that ended in a truce. The negative relationship between treaties and peacekeeping (in cases with no clear victor) is not robust when we separate UN from non-UN peacekeeping, and is less true for multidimensional peacekeeping (when examined

\footnotetext{
${ }^{27}$ Breaking down the 1947-1999 period by UN vs. non-UN peacekeeping adds very little information as there were only 5 cases of the former and 2 of the latter before 1989 .

28 The three types of consent-based peacekeeping may also have different determinants. Unfortunately we do not have enough data to perform multinomial regression for all of the categories separately. I examined each mission type on its own by running four separate logistic regressions (results not shown). In general, the three types of consent-based missions had similar results. When there are important differences, I note these in the discussion that follows.

${ }^{29}$ Robust standard errors are calculated assuming that observations between countries are independent but that observations within countries (and within the former Soviet Union) are not necessarily independent of each other.

${ }^{30}$ Non-UN missions were deployed after victories by the rebels in Iraq (Kurds) in 1991, in Chad, Haiti, and Rwanda in 1994, and by the government in Yemen also in 1994. Note that in some cases the D\&S coding of victory is largely due to the effects of this intervention, as in Iraq, so that the direction of the causal arrow is unclear.
} 
TABle 4. Where Do Peacekeepers Go?

Logistic Regressions

\begin{tabular}{|c|c|c|c|c|}
\hline & \multirow{2}{*}{$\frac{\text { Post-WWII }}{\text { All Peacekeeping }}$} & \multicolumn{3}{|c|}{ Post-Cold War } \\
\hline & & All Peacekeeping & UN Peacekeeping & Non-UN Peacekeeping \\
\hline Victory & $\begin{array}{c}-3.53^{* * * *} \\
(1.01)\end{array}$ & $\begin{array}{c}-2.44^{* * *} \\
(1.14)\end{array}$ & $\begin{array}{r}-2.26^{*} \\
(1.33)\end{array}$ & $\begin{array}{c}1.33 \\
(1.66)\end{array}$ \\
\hline Treaty & $\begin{array}{r}-1.04 \\
(1.06)\end{array}$ & $\begin{array}{r}-1.44^{*} \\
(0.82)\end{array}$ & $\begin{array}{c}1.15 \\
(1.24)\end{array}$ & $\begin{array}{c}0.26 \\
(1.62)\end{array}$ \\
\hline Identity War & $\begin{array}{c}0.48 \\
(0.42)\end{array}$ & $\begin{array}{c}0.69 \\
(0.86)\end{array}$ & $\begin{array}{c}0.66 \\
(0.82)\end{array}$ & $\begin{array}{c}0.51 \\
(0.69)\end{array}$ \\
\hline Cost of War & $\begin{array}{c}0.07 \\
(0.16)\end{array}$ & $\begin{array}{c}0.13 \\
(0.19)\end{array}$ & $\begin{array}{c}0.12 \\
(0.19)\end{array}$ & $\begin{array}{c}0.06 \\
(0.19)\end{array}$ \\
\hline Duration of War & $\begin{array}{r}-0.002 \\
(0.003)\end{array}$ & $\begin{array}{r}-0.004 \\
(0.004)\end{array}$ & $\begin{array}{r}-0.003 \\
(0.005)\end{array}$ & $\begin{array}{c}-0.009^{* * * *} \\
(0.004)\end{array}$ \\
\hline Many Factions & $\begin{array}{c}0.48 \\
(0.55)\end{array}$ & $\begin{array}{c}0.93 \\
(0.82)\end{array}$ & $\begin{array}{l}1.67 * \\
(0.99)\end{array}$ & $\begin{array}{c}0.59 \\
(0.79)\end{array}$ \\
\hline Primary Commodity Exports & $\begin{array}{c}1.45 \\
(3.77)\end{array}$ & $\begin{array}{c}1.27 \\
(5.40)\end{array}$ & $\begin{array}{c}-9.35^{* * *} \\
(4.40)\end{array}$ & $\begin{array}{c}2.30 \\
(4.53)\end{array}$ \\
\hline Development & $\begin{array}{c}0.0006^{*} \\
(0.0003)\end{array}$ & $\begin{array}{c}0.0004 \\
(0.0003)\end{array}$ & $\begin{array}{c}0.0002 \\
(0.0006)\end{array}$ & $\begin{array}{c}0.0005 \\
(0.0004)\end{array}$ \\
\hline Prior Democracy & $\begin{array}{c}-0.04 \\
(0.06)\end{array}$ & $\begin{array}{c}0.05 \\
(0.09)\end{array}$ & $\begin{array}{c}0.04 \\
(0.13)\end{array}$ & $\begin{array}{l}0.22^{* *} \\
(0.10)\end{array}$ \\
\hline Government Army Size & $\begin{array}{c}-0.003^{* *} \\
(0.001)\end{array}$ & $\begin{array}{c}-0.003^{* *} \\
(0.001)\end{array}$ & $\begin{array}{c}-0.005^{* *} \\
(0.002)\end{array}$ & $\begin{array}{r}-0.003^{*} \\
(0.002)\end{array}$ \\
\hline Constant & $\begin{array}{c}0.73 \\
(1.95)\end{array}$ & $\begin{array}{c}0.37 \\
(2.18)\end{array}$ & $\begin{array}{r}-0.88 \\
(2.54)\end{array}$ & $\begin{array}{r}-2.89 \\
(2.55)\end{array}$ \\
\hline $\mathrm{N}$ & 110 & 52 & 52 & 52 \\
\hline Pseudo $\mathrm{R}^{2}$ & 0.39 & 0.31 & 0.44 & 0.26 \\
\hline Log Likelihood & -44.05 & -23.07 & -20.19 & -25.90 \\
\hline
\end{tabular}

Coefficients are reported. Robust standard errors (cases clustered by country) are given in parentheses. $* \mathrm{p} \leqslant 0.10 ; * * \mathrm{p} \leqslant 0.05 ; * * * \mathrm{p} \leqslant 0.01 ;$ two-tailed test.

on its own), but we can confidently reject the hypothesis that peacekeepers are more likely to intervene when a formal treaty has been signed. ${ }^{31}$

There is no statistically significant relationship between peacekeeping and identity conflicts. $^{32}$ Nor is there strong evidence that the cost of war is related to the probability of intervention. The coefficient for the war's death toll is only statistically significant (and only marginally so) for enforcement missions. The lack of a strong relationship stands in contrast to Gilligan and Stedman's (2001) finding, noted above, that the UN tends to intervene more quickly in the most costly civil wars. ${ }^{33}$ And it suggests a disheartening possibility. Because Gilligan and Stedman use the total number of deaths in the war (rather than the number of deaths up to the point of intervention) as their independent variable, their finding may suggest not that the

\footnotetext{
${ }^{31}$ Note that my interpretation differs from the argument of Gilligan and Stedman (2001) that the lack of robust findings of a positive relationship between treaties and peacekeeping is due to multicollinearity in the data. Because they do not control for whether or not the war ends in victory, their treaty coefficient is picking up the UN's proclivity to go where conflicts end with a treaty rather than either a truce or a victory.

${ }^{32}$ When examined in separate logistic regressions, observer missions appear to be less likely in wars between groups defined by ethnicity or religion, while traditional peacekeeping forces are more likely in identity wars. Given the well-known problems of distinguishing "identity" wars from "ideological" wars (for example, which is Angola? D\&S code it as an identity conflict, but during the Cold War most outside observers dubbed it an ideological conflict), I am inclined to suspect that the difference between observer missions and traditional peacekeeping in this regard is spurious, but it is an intriguing finding, perhaps worthy of further investigation.

${ }^{33}$ Note that my research method differs from theirs because my concern is with where peacekeepers get sent, and what effect they have after the fighting is over, not on how long it took them to get there.
} 
TABle 5. Where Do Peacekeepers Go? Consent-Based vs. Enforcement Missions Multinomial Logistic Regression: Post-Cold War (Includes UN and Non-UN Missions)

\begin{tabular}{|c|c|c|}
\hline & Consent-Based Peacekeeping & Enforcement Missions \\
\hline Victory & $\begin{array}{c}-4.22^{* * * *} \\
(1.54)\end{array}$ & $\begin{array}{r}-1.29 \\
(2.02)\end{array}$ \\
\hline Treaty & $\begin{array}{l}-3.23^{* * * *} \\
(1.06)\end{array}$ & $\begin{aligned}-1.16 \\
(1.61)\end{aligned}$ \\
\hline Identity War & $\begin{array}{r}-0.40 \\
(0.90)\end{array}$ & $\begin{array}{c}0.11 \\
(0.99)\end{array}$ \\
\hline Cost of War & $\begin{array}{r}-0.09 \\
(0.21)\end{array}$ & $\begin{array}{r}0.50^{*} \\
(0.27)\end{array}$ \\
\hline Duration of War (see note below) & $\begin{array}{c}0.009 \\
(0.006)\end{array}$ & $\begin{array}{c}-0.03^{* * * *} \\
(0.01)\end{array}$ \\
\hline Primary Commodity Exports & $\begin{array}{l}0.98 \\
(7.55)\end{array}$ & $\begin{array}{c}2.70 \\
(7.05)\end{array}$ \\
\hline Development & $\begin{array}{c}0.0004 \\
(0.0005)\end{array}$ & $\begin{array}{c}0.0009 \\
(0.0007)\end{array}$ \\
\hline Prior Democracy & $\begin{array}{c}0.03 \\
(0.09)\end{array}$ & $\begin{array}{c}0.12 \\
(0.18)\end{array}$ \\
\hline Government Army Size & $\begin{array}{c}-0.009 * * * * \\
(0.003)\end{array}$ & $\begin{array}{r}-0.002 \\
(0.002)\end{array}$ \\
\hline Constant & $\begin{array}{l}4.15^{*} \\
(2.48)\end{array}$ & $\begin{array}{r}-4.19 \\
(3.84)\end{array}$ \\
\hline 52 & & \\
\hline $\begin{array}{lr}\text { Pseudo R } & \\
\text { Log Likelihood } & 0.41 \\
& -32.84\end{array}$ & & \\
\hline
\end{tabular}

Coefficients are reported. Robust standard errors (cases clustered by country) are given in parentheses. $* \mathrm{p} \leqslant 0.10 ; * * \mathrm{p} \leqslant 0.05 ; * * * \mathrm{p} \leqslant 0.01 ;$ two-tailed test.

Note: Enforcement missions always involved wars with more than two factions, but the number of factions has no significant effect on the likelihood of consent-based missions. However, when the number of factions is controlled for in a logit of consent-based missions, the duration of war has a significant positive effect (coefficient $=0.16$, RSE $=0.007, \mathrm{p}=0.015)$.

UN responds quickly to deadly wars, but rather that when the UN intervenes early in a conflict, the death toll tends to rise (this was dramatically the case, for example, in Rwanda where the genocide took place after UN intervention). The D\&S data simply do not allow us to know whether cost causes intervention or the other way round.

The effect of the duration of war on the deployment of peacekeepers depends on the type of mission. Enforcement missions (and non-UN missions) are significantly less likely in long wars, while consent-based peacekeeping is, if anything, more likely after long conflicts. ${ }^{34}$ Peacekeeping seems generally more likely when there are three or more factions in the fight than in simpler two-way conflicts, particularly after the Cold War, but this is driven entirely by Chapter VII enforcement missions. In every enforcement case there were at least three parties to the conflict. ${ }^{35}$ For consent-based forms of intervention, there is no significant relationship.

\footnotetext{
${ }^{34}$ When examined separately, the positive relationship is statistically significant for observer missions and multidimensional peacekeeping, but not for traditional peacekeeping. Note also that the negative relationship between duration and Chapter VII missions may be because enforcement missions bring an early halt to the fighting.

${ }^{35}$ For example, there were three factions each in Georgia-Abkhazia, Sierra Leone, and Rwanda, and five in Bosnia, all of which had enforcement missions. Logit models cannot estimate coefficients when a variable perfectly predicts the outcome, as having more than two factions does for enforcement, so this variable is not included in Table 4 (see note in table). The bivariate relationship between multiparty wars and enforcement is significant, however. The probability of seeing such an "empty cell" in our data if no true relationship existed is less than 0.01 $\left(\operatorname{Pr}\left(\chi^{2}\right)=0.003\right)$.
} 
Since 1989, the UN has been less likely to send peacekeepers to states with a high dependence on primary commodity exports. However, this finding does not apply to peacekeeping in general, which is, if anything, more likely in states with highly lootable commodities. It is possible that when intervention is required and access to primary commodities is at stake, regional powers would rather keep the peace themselves than entrust the job to the UN. ${ }^{36}$ During the Cold War, levels of development (or at least of the electricity consumption proxy) were positively associated with the probability of peacekeeping, but this relationship drops away, becoming insignificant after the Cold War.

Since 1989, peacekeeping has been more likely in countries that enjoyed higher levels of democracy before the war, but the relationship is only significant for nonUN peacekeeping. Not surprisingly, this effect is strongest for multidimensional peacekeeping operations, which generally include electoral observation as one part of their mission. ${ }^{37}$

Peacekeepers, especially consent-based missions, are much less likely to be deployed to states that have large armies. It is no surprise, of course, that peacekeepers have not been deployed to civil wars within China or Russia, but this relationship is not simply a reflection of permanent Security Council membership. States with relatively large armies but no veto on the Security Council, such as Nigeria, Mexico, India, and the Philippines, have all resisted peacekeeping in their own civil wars, even as they have participated in peacekeeping missions elsewhere. The only peacekeeping in a country with a larger than average army (for those that experience civil war) is the enforcement mission in Iraq, an exception that proves the rule. ${ }^{38}$

In sum, the answer to the question where do peacekeepers get sent is quite complicated. It depends on whether we are talking about UN peacekeeping or missions by other actors, and it depends on what type of peacekeeping we are interested in. We do not have a highly predictive model of peacekeeping deployment. ${ }^{39}$ But to the extent that there is a pattern, we can see that, in several respects at least, consent-based peacekeepers tend to get sent to the hard cases rather than the easy ones. Peace is generally more stable after decisive victories than after wars that end in a tie, and peacekeepers are usually deployed where there was no clear winner in the war. Moreover, peacekeepers are no more likely to deploy when belligerents have signaled their will for peace in a formal treaty; if anything, just the opposite is true. If renewed conflict is less likely in states with large armies, a hypothesis I will examine below, the fact that peacekeepers tend to shy away from militarily strong states also strengthens the conclusion that peacekeepers go where they are most needed rather than where peace is easy to keep in any case. As noted above, this is not an exhaustive explanation of decisions to intervene by the international community, but it does suggest that consent-based peacekeeping missions tend to be sent to more difficult cases. Just as sicker patients are more likely to receive medical care, places in which the danger of another war is higher are more likely to receive peacekeeping. And just as a study of the efficacy of medical treatment must control for how sick patients were to begin with, an examination of the effects of peacekeeping must control for the baseline prospects of peace.

\footnotetext{
${ }^{36}$ This is an admittedly post-hoc explanation for the puzzling negative coefficient for UN peacekeeping in Table 4. Thanks to Amitabh Dubey for suggesting it as a possibility.

${ }^{37}$ Observer missions, on the other hand, are less likely in more democratic states.

38 The recent peacekeeping in Indonesia-East Timor is a notable exception not included in this data set because the war ended after the D\&S data set was created.

${ }^{39}$ As the pseudo- $\mathrm{R}^{2}$ values indicate, these models account for only $25-45 \%$ of the variation in peacekeeping deployment.
} 


\section{Does Peacekeeping Work?}

To test the effects of peacekeeping on the durability of peace, I employ duration analysis (also sometimes known as hazard or survival analysis), specifically a Cox proportional hazards model. ${ }^{40}$ This model estimates the effects of independent variables on the risk, or "hazard" of peace failing in a particular time period, given that peace has lasted up to that time period. It can thus tell us whether the risk of renewed warfare is lower after wars that end in a victory, say, or when peacekeepers are present. ${ }^{41}$ In the tables that follow, hazard ratios are reported, rather than coefficients that might be more familiar to readers used to linear or logistic regression. Hazard ratios are interpreted relative to 1 : a hazard ratio greater than 1 means that high values of that variable increase the risk of another war (that is, they are associated with peace that fails more quickly); hazard ratios less than 1 indicate variables that decrease the hazard (i.e., that are associated with more durable peace). ${ }^{42}$ For example, a dummy variable with a hazard ratio of 2 would indicate a doubling of the risk of war, while a hazard ratio of 0.66 would suggest that the risk of war drops by a third.

Table 6 shows the results of this duration analysis for the entire post-WWII period (1947-1999). Table 7 focuses on the era of peacekeeping activism in civil wars, the post-Cold War period (1989-1999). Table 8 examines the effects of different mission types after $1989 .{ }^{43}$ All three tables use the time-varying coding of peacekeeping. ${ }^{44}$

Looking first at Table 6 , there is some evidence that peacekeeping works in the full post-WWII period. The hazard ratios of just under 0.7 for all peacekeeping missions and only those performed by the UN (columns 1 and 2) indicate that the risk of another war drops by more than $30 \%$ (from 1.0 to 0.68 ) when peacekeepers are present (the effect is much smaller for non-UN peacekeeping in column 3). ${ }^{45}$ But these hazard ratios are not statistically indistinguishable from 1 - we cannot conclude with confidence that peacekeeping works in civil wars when we look at its entire history (since 1947), lumping Cold War and post-Cold War cases together.

As expected, things change with the end of the Cold War. After 1989, the positive effect of peacekeeping on peace is much stronger (Table 7). Ceteris paribus, when the international community deploys peacekeepers the risk of another round of fighting drops by almost $70 \%$ (from 1.00 to 0.32 ). It is statistically unlikely (less than $5 \%$ chance) that we would see such a large effect if no true relationship between peacekeeping and peace existed. The size of the effect is a bit smaller for UN peacekeeping, which reduces the hazard of war by about half. Non-UN missions appear to have a larger effect (smaller hazard ratio) than UN missions, but because of the smaller number of such missions, our estimates are less precise. The larger standard error here means that this hazard ratio just misses the rather lax $10 \%$

\footnotetext{
40 The Cox model does not assume a particular shape for the "baseline hazard," that is, whether the risk of another war goes up or down the longer peace lasts, or even whether the hazard is monotonic. Estimates using a parametric model, the Weibull distribution, which can be more efficient with small samples, are not substantially different and so are not reported here.

${ }^{41}$ For a good introduction to duration models and their use in political science, see Box-Steffensmeier and Jones (1997).

${ }^{42}$ As in the logistic regressions above, I calculate robust standard errors assuming independence between observations in different countries, but not necessarily between observations from the same country. Note that because the tables report hazard ratios, which are exponentiated, rather than coefficients, the two-to-one rule of thumb for comparing coefficients to standard errors to determine significance does not apply.

43 There are not enough cases before 1989 for such a breakdown by mission type to tell us much for the earlier period.

${ }^{44}$ In all of these models, global tests based on Schoenfeld residuals indicate that the proportional hazards assumption undergirding the Cox model is appropriate. On the importance of testing the proportional hazards assumption, see Box-Steffensmeier, Reiter, and Zorn (2003).

45 The results are the same whether separate models are run for UN and non-UN peacekeeping (as in Tables 5 and 6 ) or they are included together as two dummy variables in one regression.
} 
TABle 6. Effects on the Duration of Peace: Post-World War II

Cox Proportional Hazards Model: Time-Varying Peacekeeping

\begin{tabular}{|c|c|c|c|}
\hline & All Peacekeeping & UN Peacekeeping & Non-UN Peacekeeping \\
\hline \multirow[t]{2}{*}{ Peacekeeping } & 0.68 & 0.68 & 0.92 \\
\hline & $(0.32)$ & $(0.25)$ & $(0.52)$ \\
\hline \multirow[t]{2}{*}{ Victory } & $0.15^{* *}$ & $0.17^{* * * *}$ & $0.20 * *$ \\
\hline & $(0.11)$ & $(0.11)$ & $(0.13)$ \\
\hline \multirow[t]{2}{*}{ Treaty } & 0.45 & 0.49 & 0.52 \\
\hline & $(0.30)$ & $(0.30)$ & $(0.34)$ \\
\hline \multirow[t]{2}{*}{ Identity War } & 1.51 & 1.57 & 1.52 \\
\hline & $(0.57)$ & $(0.58)$ & $(0.57)$ \\
\hline \multirow{2}{*}{ Cost of War } & $1.24^{* * *}$ & $1.24^{* * *}$ & $1.22 * *$ \\
\hline & $(0.12)$ & $(0.12)$ & $(0.11)$ \\
\hline \multirow[t]{2}{*}{ Duration of War } & 0.996 & 0.996 & 0.996 \\
\hline & $(0.003)$ & $(0.003)$ & $(0.003)$ \\
\hline \multirow[t]{2}{*}{ Many Factions } & 0.86 & 0.88 & 0.93 \\
\hline & $(0.35)$ & $(0.32)$ & $(0.34)$ \\
\hline \multirow[t]{2}{*}{ Primary Commodity Exports } & $26.90 *$ & $25.90 *$ & $30.06^{*}$ \\
\hline & $(50.33)$ & $(49.00)$ & $(56.87)$ \\
\hline \multirow[t]{2}{*}{ Development } & $0.999 * *$ & $0.999^{* * *}$ & $0.999 * *$ \\
\hline & $(0.0004)$ & $(0.0003)$ & $(0.0004)$ \\
\hline \multirow[t]{2}{*}{ Prior Democracy } & 0.98 & 0.97 & 0.98 \\
\hline & $(0.03)$ & $(0.03)$ & $(0.03)$ \\
\hline \multirow{2}{*}{ Government Army Size } & $0.999 *$ & 0.999 & 0.999 \\
\hline & $(0.0005)$ & $(0.0005)$ & $(0.0005)$ \\
\hline Number of Subjects & 109 & 109 & 109 \\
\hline $\mathrm{N}$ & 357 & 357 & 357 \\
\hline Log Likelihood & -169.63 & -169.65 & -169.98 \\
\hline
\end{tabular}

Hazard ratios are reported. Robust standard errors (cases clustered by country) are given in parentheses. $* \mathrm{p} \leqslant 0.10 ; * * \mathrm{p} \leqslant 0.05 ; * * * \mathrm{p} \leqslant 0.01 ;$ two-tailed test.

mark for statistical significance $(\mathrm{p}=.12)$. We should therefore have less confidence in this result.

In Table 8, four dummy variables indicate the effects of different types of peacekeeping missions relative to cases with no peacekeeping (the omitted category). Over the 50-year period, consent-based peacekeeping is associated with a drop in the risk of war and these effects are jointly significant, but only at the 0.10 level (hence the single asterisk after the "js" notation). ${ }^{46}$ Observer missions appear to have the largest effect on the durability of peace, reducing the hazard of peace failing by $80 \%$. Notice, however, the hazard ratio for enforcement missions (1.88). This means that in the post-WWII period, the risk of war was almost $90 \%$ higher when an enforcement mission was in place. If anything, enforcement missions are associated with unstable peace, though this finding is not statistically significant.

In the post-Cold War era, all four types of missions have decreased the risk of another war, all else equal. Traditional peacekeeping missions and observer missions have been the most successful, reducing the risk of war by about $86 \%$ and $81 \%$, respectively. Multidimensional peacekeeping appears to cut the risk of war by more than half, and enforcement missions by just under half. Taken individually, only one of the peacekeeping hazard ratios is statistically significant, but jointly they pass the significance test with flying colors (in a joint test, $\operatorname{Pr}\left(\chi^{2}\right)=0.015$ ).

\footnotetext{
${ }^{46}$ The joint probability of observing the hazard ratios we do for observer, traditional, and multidimensional peacekeeping, if peacekeeping truly had no effect, is 0.07 . Joint probability tests are appropriate for categorical independent variables, such as peacekeeping mission type.
} 
TABLE 7. Effects on the Duration of Peace: Post-Cold War

Cox Proportional Hazards Model: Time-Varying Peacekeeping

\begin{tabular}{|c|c|c|c|}
\hline & All Peacekeeping & UN Peacekeeping & Non-UN Peacekeeping \\
\hline \multirow[t]{2}{*}{ Peacekeeping } & $0.32 * *$ & $0.51 *$ & 0.34 \\
\hline & $(0.18)$ & $(0.19)$ & $(0.23)$ \\
\hline \multirow[t]{2}{*}{ Victory } & 0.15 & 0.24 & 0.31 \\
\hline & $(0.20)$ & $(0.29)$ & $(0.35)$ \\
\hline \multirow[t]{2}{*}{ Treaty } & 0.54 & 0.87 & 0.78 \\
\hline & $(0.64)$ & $(0.93)$ & $(0.80)$ \\
\hline \multirow[t]{2}{*}{ Identity War } & 2.33 & 2.36 & 2.05 \\
\hline & $(1.90)$ & $(1.80)$ & $(1.54)$ \\
\hline \multirow{2}{*}{ Cost of War } & $1.43^{*}$ & $1.37^{*}$ & $1.36^{*}$ \\
\hline & $(0.29)$ & $(0.23)$ & $(0.24)$ \\
\hline \multirow[t]{2}{*}{ Duration of War } & $0.99 *$ & $0.99 *$ & 0.99 \\
\hline & $(0.005)$ & $(0.005)$ & $(0.01)$ \\
\hline \multirow[t]{2}{*}{ Many Factions } & 0.93 & 1.04 & 1.11 \\
\hline & $(0.60)$ & $(0.60)$ & $(0.66)$ \\
\hline \multirow[t]{2}{*}{ Primary Commodity Exports } & 9.07 & 5.52 & 7.68 \\
\hline & $(30.79)$ & $(18.05)$ & $(26.70)$ \\
\hline \multirow[t]{2}{*}{ Development } & $0.999 *$ & $0.999 * *$ & 0.999 \\
\hline & $(0.0006)$ & $(0.001)$ & $(0.001)$ \\
\hline \multirow[t]{2}{*}{ Prior Democracy } & 1.02 & 1.01 & 1.07 \\
\hline & $(0.08)$ & $(0.08)$ & $(0.07)$ \\
\hline \multirow{2}{*}{ Government Army Size } & 1.001 & 1.001 & 1.001 \\
\hline & $(0.001)$ & $(0.001)$ & $(0.002)$ \\
\hline Number of Subjects & 51 & 51 & 51 \\
\hline $\mathrm{N}$ & 122 & 122 & 122 \\
\hline Log Likelihood & -59.00 & -60.10 & -59.15 \\
\hline
\end{tabular}

Hazard ratios are reported. Robust standard errors (cases clustered by country) are given in parentheses. $* \mathrm{p} \leqslant 0.10 ; * * \mathrm{p} \leqslant 0.05 ; * * * \mathrm{p} \leqslant 0.01 ;$ two-tailed test.

The analyses in Tables $6-8$ calculate the effect of peacekeeping in a way that probably underestimates the true influence of peacekeepers. Use of the timevarying version of the peacekeeping variables means that if peacekeepers complete their mission and leave, and peace continues to hold, this counts against the hypothesis that peacekeeping has an effect. ${ }^{47}$ So peacekeepers are not given any credit for peace lasting after they are gone. But for the UN and other policymakers concerned with peacekeeping, true success is not just preventing another war, but the ability to go home and still have peace hold; to create a selfsustaining peace.

To test the effects of peacekeeping that linger after the mission departs, a timeconstant coding of peacekeeping is more appropriate. In Table 9, I use measures of peacekeeping that denote whether peacekeepers were deployed and the type of mission, no matter how long the mission stayed. ${ }^{48}$ Over the 1947-1999 time period, the presence of peacekeepers reduces the risk of another war by more than $55 \%$. As

\footnotetext{
${ }^{47}$ The model assumes that if a purported cause (peacekeeping) is taken away and the result (peace) still holds, this is evidence that it is not the real cause. It cannot account for effects that last after the "treatment" is withdrawn.

48 These models also pass global tests of the proportional-hazards assumption. However, as we might expect in a time-constant version of the data, the effects of some individual variables indicate non-proportionality over time. Tests based on Schoenfeld residuals suggest that the effect of peacekeeping declines over time, presumably as missions depart, so that our estimates (which assume a constant effect over time and so calculate the average) are probably too low early on and too high as peace continues to last. The opposite is true for the effects of identity conflicts, war cost, lootable commodities, and prior democracy.
} 
TAble 8. Effects on the Duration of Peace by Mission Type: Post-Cold War

Cox Proportional Hazards Model: Time-Varying Peacekeeping

\begin{tabular}{|c|c|c|}
\hline & Post-WWII & Post-Cold War \\
\hline Observer Missions & $\begin{array}{l}0.20^{* *} \mathrm{js} * \\
(0.13)\end{array}$ & $\begin{array}{l}0.19 \mathrm{jj}^{* * *} \\
(0.22)\end{array}$ \\
\hline Traditional Peacekeeping & $\begin{array}{l}0.46 \text { js* } \\
(0.29)\end{array}$ & $\begin{array}{l}0.14^{*} \mathrm{js}^{* * *} \\
(0.15)\end{array}$ \\
\hline Multidimensional Peacekeeping & $\begin{array}{l}0.72 \mathrm{js}^{*} \\
(0.46)\end{array}$ & $\begin{array}{l}0.47 \mathrm{jj}^{* * *} \\
(0.33)\end{array}$ \\
\hline Enforcement & $\begin{array}{c}1.88 \\
(1.26)\end{array}$ & $\begin{array}{l}0.57 \mathrm{js}^{* *} \\
(0.57)\end{array}$ \\
\hline Victory & $\begin{array}{l}0.09^{* * * \cdots *} \\
(0.07)\end{array}$ & $\begin{array}{c}0.12 \\
(0.16)\end{array}$ \\
\hline Treaty & $\begin{array}{c}0.35 \\
(0.25)\end{array}$ & $\begin{array}{c}0.36 \\
(0.42)\end{array}$ \\
\hline Identity War & $\begin{array}{c}1.32 \\
(0.53)\end{array}$ & $\begin{array}{l}1.60 \\
(1.77)\end{array}$ \\
\hline Cost of War & $\begin{array}{l}1.24^{* *} \\
(0.12)\end{array}$ & $\begin{array}{c}1.38 \\
(0.32)\end{array}$ \\
\hline Duration of War & $\begin{array}{c}0.996 \\
(0.002)\end{array}$ & $\begin{array}{c}0.99^{*} \\
(0.01)\end{array}$ \\
\hline Many Factions & $\begin{array}{c}0.64 \\
(0.25)\end{array}$ & $\begin{array}{c}0.60 \\
(0.56)\end{array}$ \\
\hline Primary Commodity Exports & $\begin{array}{l}20.77 * \\
(36.63)\end{array}$ & $\begin{array}{c}7.23 \\
(23.31)\end{array}$ \\
\hline Development & $\begin{array}{r}0.999^{* * *} \\
(0.0004)\end{array}$ & $\begin{array}{r}0.999^{*} \\
(0.001)\end{array}$ \\
\hline Prior Democracy & $\begin{array}{c}0.96 \\
(0.03)\end{array}$ & $\begin{array}{l}1.08 \\
(0.11)\end{array}$ \\
\hline Government Army Size & $\begin{array}{c}0.999^{*} \\
(0.0004)\end{array}$ & $\begin{array}{l}1.000 \\
(0.001)\end{array}$ \\
\hline Number of Subjects & 109 & 51 \\
\hline $\mathrm{N}$ & 357 & 122 \\
\hline Log Likelihood & -165.94 & -57.81 \\
\hline
\end{tabular}

Hazard ratios are reported. Robust standard errors (cases clustered by country) are given in parentheses. $* \mathrm{p} \leqslant 0.10 ; * * \mathrm{p} \leqslant 0.05 ; * * * \mathrm{p} \leqslant 0.01 ;$ two-tailed test; js denotes joint significance.

above, consent-based peacekeeping is much more effective than enforcement missions, which are actually associated with shorter peace (though not significantly so). Looking just at the post-Cold War period in which most peacekeeping in civil wars has taken place, we see that the presence of international personnel reduces the risk of another war dramatically, by $84 \%$, and we can be quite confident that this result is not an artifact of chance $(\mathrm{p}=0.008)$. In the post-Cold War period, all forms of peacekeeping reduce the risk of another war, but again, the smaller hazard ratios for consent-based peacekeeping indicate that it is more effective than are enforcement missions.

In short, peacekeeping helps maintain peace. In the decade following the Cold War, when the international community became involved in peacekeeping in internal war, its efforts to prevent recurrent fighting have worked. If we give credit to peacekeepers for peace that holds after they depart, then the effects of peacekeeping are overwhelming. But even if we use a more stringent measure of their influence, it is clear that peacekeeping works. Because of the selection bias in the data - the probable underreporting of very short lived cease-fires when no peacekeepers were present - it is likely that peacekeeping has been even more 
TABle 9. Effects on the Duration of Peace: Time-Constant Peacekeeping

Cox Proportional Hazards Model

\begin{tabular}{|c|c|c|c|c|}
\hline & \multicolumn{2}{|c|}{ Post-WWII } & \multicolumn{2}{|c|}{ Post-Cold War } \\
\hline & Any Peacekeeping & By Mission Type & Any Peacekeeping & By Mission Type \\
\hline Peacekeeping & $\begin{array}{c}0.43^{*} \\
(0.19)\end{array}$ & & $\begin{array}{l}0.16^{* * * * *} \\
(0.11)\end{array}$ & \\
\hline Observer Missions & & $\begin{array}{l}0.12 * * * j \mathrm{js} * * \\
(0.09)\end{array}$ & & $\begin{array}{l}0.06^{*} \mathrm{js}^{*} \\
(0.10)\end{array}$ \\
\hline Traditional Peacekeeping & & $\begin{array}{l}0.38 * \mathrm{js} * * \\
(0.19)\end{array}$ & & $\begin{array}{l}0.17 * \mathrm{js} * \\
(0.16)\end{array}$ \\
\hline Multidimensional Peacekeeping & & $\begin{array}{l}0.33 \mathrm{js} \text { *** } \\
(0.24)\end{array}$ & & $\begin{array}{l}0.16 \text { **js* } \\
(0.13)\end{array}$ \\
\hline Enforcement & & $\begin{array}{c}1.41 \\
(0.95)\end{array}$ & & $\begin{array}{c}0.27 \\
(0.28)\end{array}$ \\
\hline Victory & $\begin{array}{l}0.10^{* * * *} \\
(0.08)\end{array}$ & $\begin{array}{l}0.07^{* * * *} \\
(0.06)\end{array}$ & $\begin{array}{c}0.11 \\
(0.16)\end{array}$ & $\begin{array}{c}0.08 \\
(0.15)\end{array}$ \\
\hline Treaty & $\begin{array}{c}0.44 \\
(0.27)\end{array}$ & $\begin{array}{c}0.39 \\
(0.27)\end{array}$ & $\begin{array}{c}0.49 \\
(0.62)\end{array}$ & $\begin{array}{c}0.38 \\
(0.51)\end{array}$ \\
\hline Identity War & $\begin{array}{c}1.41 \\
(0.57)\end{array}$ & $\begin{array}{l}1.20 \\
(0.50)\end{array}$ & $\begin{array}{c}2.32 \\
(2.30)\end{array}$ & $\begin{array}{c}1.84 \\
(2.19)\end{array}$ \\
\hline Cost of War & $\begin{array}{l}1.26^{* * *} \\
(0.12)\end{array}$ & $\begin{array}{l}1.27^{* * *} \\
(0.12)\end{array}$ & $\begin{array}{l}1.53^{*} \\
(0.38)\end{array}$ & $\begin{array}{c}1.47 \\
(0.39)\end{array}$ \\
\hline Duration of War & $\begin{array}{c}0.995 \\
(0.003)\end{array}$ & $\begin{array}{c}0.996 \\
(0.004)\end{array}$ & $\begin{array}{c}0.99 \\
(0.01)\end{array}$ & $\begin{array}{c}0.99 \\
(0.01)\end{array}$ \\
\hline Many Factions & $\begin{array}{c}0.86 \\
(0.33)\end{array}$ & $\begin{array}{c}0.66 \\
(0.24)\end{array}$ & $\begin{array}{c}1.18 \\
(0.72)\end{array}$ & $\begin{array}{c}1.17 \\
(1.12)\end{array}$ \\
\hline Primary Commodity Exports & $\begin{array}{r}31.93^{*} \\
(57.66)\end{array}$ & $\begin{array}{l}47.60 * * \\
(78.93)\end{array}$ & $\begin{array}{c}33.38 \\
(138.96)\end{array}$ & $\begin{array}{c}70.93 \\
(244.26)\end{array}$ \\
\hline Development & $\begin{array}{l}0.999 * * \\
(0.000)\end{array}$ & $\begin{array}{l}0.999 * * \\
(0.000)\end{array}$ & $\begin{array}{r}0.999 * \\
(0.001)\end{array}$ & $\begin{array}{c}0.999 \\
(0.001)\end{array}$ \\
\hline Prior Democracy & $\begin{array}{c}0.98 \\
(0.03)\end{array}$ & $\begin{array}{c}0.95 \\
(0.03)\end{array}$ & $\begin{array}{c}1.03 \\
(0.10)\end{array}$ & $\begin{array}{c}0.99 \\
(0.14)\end{array}$ \\
\hline Government Army Size & $\begin{array}{c}0.999 * \\
(0.000)\end{array}$ & $\begin{array}{c}0.999^{*} \\
(0.000)\end{array}$ & $\begin{array}{l}1.000 \\
(0.001)\end{array}$ & $\begin{array}{l}1.001 \\
(0.002)\end{array}$ \\
\hline $\mathrm{N}$ & 109 & 109 & 51 & 51 \\
\hline Log Likelihood & -168.30 & -164.10 & -57.31 & -56.58 \\
\hline
\end{tabular}

Hazard ratios are reported. Robust standard errors (cases clustered by country) are given in parentheses. $* \mathrm{p} \leqslant 0.10 ; * * \mathrm{p} \leqslant 0.05 ; * * * \mathrm{p} \leqslant 0.01 ;$ two-tailed test; js denotes joint significance.

effective than these statistics indicate. We can thus be quite confident in the finding that peacekeeping helps maintain peace.

\section{Other Influences on the Durability of Peace}

Tables 6-9 also tell us something about when peace will be harder or easier to maintain, whether or not the international community intervenes. As we would expect, peace tends to be quite stable after wars that end in a victory. The hazard for another war drops by about $70-90 \%$ when there is such a decisive military outcome. However, this relationship is less clear after the Cold War-large standard errors in Table 7, column 2 of Table 8 , and columns 3 and 4 of Table 9 mean that this finding is not statistically significant in the post-1989 era. The hazard ratio for formal treaties is consistently lower than 1, indicating a stabilizing effect on peace, but, surprisingly, this effect is never statistically significant. We cannot with confidence 
reject the null hypothesis that whether or not a treaty is signed makes no difference for the durability of peace. ${ }^{49}$

Peace may be harder to keep in identity conflicts than in wars fought along other kinds of lines. This effect is larger in the post-Cold War period, with the risk of another war estimated to be more than twice as high for conflicts between competing identities than for non-identity wars. But this finding is not statistically significant - it could be due to random chance in our data.

The more deadly the civil war, the harder it is to maintain peace. A high death toll apparently fuels animosity and makes post-civil war reconciliation harder. ${ }^{50}$ As noted above, the relationship is the opposite in wars between sovereign states. Perhaps the necessity of living in close contact with those responsible for the killing in civil wars accounts for this difference between intrastate and interstate wars. While particularly deadly civil wars are prone to recur, very long wars are not. The positive relationship between the length of war and the length of peace gives support to the war weariness hypothesis; those who have endured particularly drawn-out wars have, if anything, less of a tendency to fight again.

Surprisingly, I find no support for the notion that it is harder to keep peace among many factions than after simpler wars between two parties. In Tables 6 and 8 just the opposite appears to be the case, though there is no statistically significant relationship. Nor is there any relationship between prior levels of democracy and the durability of peace. ${ }^{51}$ There is some weak support for the hypothesis that the presence of easily lootable commodities makes peace harder to maintain, but this is much less pronounced (and no longer significant) after the Cold War. ${ }^{52}$ As we might expect, peace is easier to maintain in countries with higher levels of economic development. (The size of this effect appears small because of the size of the units of this measure rather than because it is substantively unimportant.) States with large military forces are less prone to the recurrence of war than are less well armed states, but this effect is only marginally significant and falls away completely after the end of the Cold War.

In sum, peace will generally be easier to maintain, all else equal, after wars that end with a decisive victory than after those that end in an informal truce. Peace will also be easier to keep after long wars, and in countries with higher levels of development. But peace will tend to be harder to maintain after very deadly wars. Other hypotheses about what makes peace easier or harder to maintain receive less consistent or robust support. During the Cold War, primary commodity exports tended to fuel renewed conflict, and powerful states were less likely to experience another war, but these findings do not hold as well in more recent conflicts. Peace may be somewhat less stable after identity conflicts and somewhat easier when a treaty has been signed, but in neither case do we see statistically significant effects. Neither the number of factions in the fight, nor prior experience with democracy, has a consistent or significant effect on the duration of peace.

\footnotetext{
${ }^{49}$ Note that both of these findings, that military victories have a sizable effect and that treaties do not, stand in contrast to those of Doyle and Sambanis (2000).

${ }^{50}$ This relationship could be spurious rather than causal. It may be that wars over particularly intractable issues tend both to have high body counts and to flare up again after a cease-fire. That longer wars tend to yield more stable peace suggests this is not the case since intractable issues should also take longer to solve. Note also that the effects on the hazard rate of both identity conflicts and the cost of war indicate some non-proportionality. Their effects appear to increase over time.

${ }^{51}$ Note that this does not contradict the findings of Dubey (2002) and Walter (2004) that democracy after the war yields more durable peace, a hypothesis not tested here. Tests of non-proportional hazards based on Schoenfeld residuals suggest that the effect of pre-war democracy may increase in importance over the life of a peace spell, and that the opposite is true for the effect of multiple factions.

${ }^{52}$ The large size of the hazard ratios for primary commodity exports reflects the unit of analysis for this variable, which ranges from 0.01 to about 0.5 .
} 


\section{Conclusion}

If peacekeeping missions were applied at random to cases of civil war, like treatments in a laboratory experiment, then a quick look at peacekeeping's record would tell us all that we needed to know. And we would conclude that the efforts of the international community would be better spent on other endeavors. But as in medicine, where the seriousness of the disease affects the level of treatment, peacekeepers tend to be sent to more difficult cases. They rarely go where war has ended in a decisive outcome, but rather try to maintain peace where both sides have the capacity to disrupt it. Nor is peacekeeping more likely where a peace treaty has been signed indicating the combatants' commitment to peace, rather the opposite is true. To assess the effects of peacekeeping accurately, we have to take this selection process into account.

Controlling as much as possible for factors that might influence the degree of difficulty of a particular case, it is clear that intervention by the international community helps maintain peace. Peacekeeping works, particularly after the Cold War when most of the attempts to keep peace after civil wars have been made. The presence of international personnel is not a silver bullet, of course, it does not guarantee lasting peace in every case, but it does tend to make peace more likely to last, and to last longer. Despite a number of well-publicized peacekeeping fiascoes in the early and mid-1990s, peacekeeping is an effective conflict management tool. The efforts of the international community to help war-torn states avoid a slide back to civil war are well worth it.

Appendix. The Cases

\begin{tabular}{|c|c|c|c|}
\hline Country & Cease-Fire & War Resumes & $\begin{array}{l}\text { PK Operation } \\
\text { (time constant) }\end{array}$ \\
\hline Afghanistan & 24 Apr 1992 & 10 Aug 1992 & 0 \\
\hline Algeria & 01 Jul 1962 & & 0 \\
\hline Angola & 31 May 1991 & 11 Oct 1992 & 2 \\
\hline Angola & 20 Nov 1994 & 04 Dec 1998 & 3 \\
\hline Argentina & 16 Sep 1955 & & 0 \\
\hline Azerbaijan & 14 May 1994 & & $2 *$ \\
\hline Bangladesh-Chittagong Hills & 18 Jan 1994 & & 0 \\
\hline Bolivia & 12 Apr 1952 & & 0 \\
\hline Burma & 01 Jan 1952 & 01 Jan 1968 & 0 \\
\hline Burma & 15 Jun 1982 & $01 \mathrm{Jul} 1983$ & 0 \\
\hline Burma & 15 Jun 1995 & & 0 \\
\hline Burundi & 18 Dec 1969 & 29 Apr 1972 & 0 \\
\hline Burundi & 17 Jun 1972 & 10 Aug 1988 & 0 \\
\hline Burundi & 20 Aug 1988 & 02 May 1991 & 0 \\
\hline Cambodia & 17 Apr 1975 & 25 Dec 1978 & 0 \\
\hline Cambodia & 23 Oct 1991 & 06 Jul 1997 & 4 \\
\hline Cambodia & 30 Nov 1998 & & 0 \\
\hline Central African Republic & 25 Jan 1997 & & $4^{* *}$ \\
\hline Chad & 21 Aug 1979 & 15 Mar 1980 & 0 \\
\hline Chad & 11 Aug 1994 & & $3 *$ \\
\hline China-Taiwan & 08 Dec 1949 & & 0 \\
\hline China-Tibet & 09 Jan 1951 & & 0 \\
\hline China & 15 Apr 1969 & & 0 \\
\hline Colombia & 01 Jan 1963 & & 0 \\
\hline Congo-Brazzaville & 24 Mar 1996 & 05 Jun 1997 & 0 \\
\hline
\end{tabular}


Appendix Continued

\begin{tabular}{|c|c|c|c|}
\hline Country & Cease-Fire & War Resumes & $\begin{array}{l}\text { PK Operation } \\
\text { (time constant) }\end{array}$ \\
\hline Congo/Zaire & 24 Nov 1965 & $05 \mathrm{Jul} 1967$ & 5 \\
\hline Congo-Kisanguni & 05 Nov 1967 & 08 Mar 1977 & 0 \\
\hline Congo-Shabba I\&II & 01 Jul 1979 & & 0 \\
\hline Congo/Zaire & 19 May 1997 & 15 Aug 1998 & 0 \\
\hline Costa Rica & 28 Apr 1948 & & 0 \\
\hline Cuba & 01 Jan 1959 & & 0 \\
\hline Cyprus & 10 Aug 1964 & $15 \mathrm{Jul} 1974$ & 3 \\
\hline Cyprus & 16 Aug 1974 & & 3 \\
\hline Djibouti & 26 Dec 1994 & & 0 \\
\hline Dominican Republic & 01 May 1965 & & $3^{*}$ \\
\hline El Salvador & 15 Dec 1992 & & 4 \\
\hline Eritrea & 21 May 1991 & & 0 \\
\hline Ethiopia-Ogaden & 01 Jan 1985 & & 0 \\
\hline Ethiopia-Ideology & 21 May 1991 & & 0 \\
\hline Georgia-Abkhazia & $27 \mathrm{Jul} 1993$ & 16 Sep 1993 & $5^{* * *}$ \\
\hline Georgia-Abkhazia & 14 May 1994 & & $5^{* * *}$ \\
\hline Georgia-Ossetia & 04 Apr 1994 & & $3^{* * *}$ \\
\hline Greece-Communists & 16 Oct 1949 & & 0 \\
\hline Guatemala & 02 Jun 1954 & 02 Nov 1966 & 0 \\
\hline Guatemala & 23 Jun 1994 & & 4 \\
\hline Haiti & $18 \mathrm{Sep} 1994$ & & $5^{* * *}$ \\
\hline India-Partition & 01 Jan 1948 & 05 Aug 1965 & 2 \\
\hline India-Sikh & 01 Jan 1994 & & 0 \\
\hline Indonesia-Moluccas & 01 Jan 1951 & & 0 \\
\hline Indonesia-Darul Islam & 23 Nov 1953 & 20 Dec 1956 & 0 \\
\hline Indonesia & $31 \mathrm{Jul} 1961$ & & 0 \\
\hline Indonesia-Aceh & $15 \mathrm{Dec} 1986$ & 01 May 1999 & 0 \\
\hline Iran-Revolution & $11 \mathrm{Feb} 1979$ & 20 Jun 1981 & 0 \\
\hline Iran & 23 Sep 1982 & & 0 \\
\hline Iraq-Shammar & 07 Apr 1959 & & 0 \\
\hline Iraq-Kurds & 11 Mar 1970 & 11 Mar 1974 & 0 \\
\hline Iraq-Kurds & 06 Mar 1975 & 03 Mar 1987 & 0 \\
\hline Iraq-Kurds & 16 Apr 1991 & & $5 *$ \\
\hline Iraq-Shia & 1994 & & $5^{*}$ \\
\hline Israel-Palestine & 13 Sep 1993 & 28 Sep 2000 & 0 \\
\hline Jordan & 05 Dec 1971 & & 0 \\
\hline Laos & 23 Aug 1975 & & 0 \\
\hline Lebanon & 24 Sep 1958 & 13 Apr 1975 & 3 \\
\hline Lebanon & $16 \mathrm{Jul} 1978$ & 14 Sep 1982 & 0 \\
\hline Lebanon & 02 May 1991 & & 3 \\
\hline Liberia & 25 Jul 1993 & 15 Sep 1993 & $5^{*}$ \\
\hline Liberia & 24 Sep 1996 & & 2 \\
\hline Malaysia & 08 Mar 1959 & & 0 \\
\hline Mali & 13 Jan 1995 & & 0 \\
\hline Mexico & 29 Jan 1994 & & 0 \\
\hline Moldova & 21 Oct 1994 & & 0 \\
\hline Morocco/W. Sahara & 06 Sep 1991 & & 2 \\
\hline Mozambique & 04 Oct 1992 & & 4 \\
\hline Namibia & 09 Apr 1989 & & 4 \\
\hline
\end{tabular}


Appendix Continued

\begin{tabular}{|c|c|c|c|}
\hline Country & Cease-Fire & War Resumes & $\begin{array}{l}\text { PK Operation } \\
\text { (time constant) }\end{array}$ \\
\hline Nicaragua & 19 Jul 1979 & 27 Nov 1981 & 0 \\
\hline Nicaragua & 04 Aug 1989 & & $2^{* * *}$ \\
\hline Nigeria-Biafra & 15 Jan 1970 & & 0 \\
\hline Nigeria-Muslim & 26 Apr 1985 & & 0 \\
\hline Northern Ireland & 31 Aug 1994 & & 0 \\
\hline Pakistan-Bangladesh & 17 Dec 1971 & & 0 \\
\hline Pakistan-Baluchistan & 31 Dec 1976 & & 0 \\
\hline Papua New Guinea & 01 Nov 1997 & & $3 *$ \\
\hline Paraguay & 15 Aug 1947 & & 0 \\
\hline Philippines & 27 Dec 1952 & & 0 \\
\hline Philippines-NPA & 15 Dec 1993 & 31 Dec 1999 & 0 \\
\hline Philippines-MNLF/MILF & 02 Sep 1996 & 31 Dec 1999 & 0 \\
\hline Romania & 22 Dec 1989 & & 0 \\
\hline Russia-Chechnya & 27 May 1996 & 15 Aug 1999 & 0 \\
\hline Rwanda & 28 Jan 1964 & 01 Oct 1990 & 0 \\
\hline Rwanda & 04 Aug 1993 & 06 Apr 1994 & $5^{* * *}$ \\
\hline Rwanda & 18 Jul 1994 & 01 Jan 1998 & $5^{* * *}$ \\
\hline Sierra Leone & 30 Nov 1996 & 15 May 1997 & 0 \\
\hline Sierra Leone & 07 Jul 1999 & 02 May 2000 & 5 \\
\hline Somalia & 26 Jan 1991 & 05 Sep 1991 & 0 \\
\hline South Africa & 10 May 1994 & & $2^{* * *}$ \\
\hline Sri Lanka (JVP I) & 30 Apr 1971 & 18 Aug 1987 & 0 \\
\hline Sri Lanka (Tamil) & 29 Jul 1987 & 10 Oct 1987 & $3 *$ \\
\hline Sri Lanka (JVP II) & 13 Nov 1989 & & $3 *$ \\
\hline Sudan & 28 Feb 1972 & 05 Jun 1983 & 0 \\
\hline Tajikistan & 18 Sep 1994 & & $5^{* * *}$ \\
\hline Thailand-Communists & 03 Jul 1984 & & 0 \\
\hline Uganda & 26 May 1966 & & 0 \\
\hline Uganda & 10 Apr 1979 & 10 Dec 1980 & 0 \\
\hline Uganda & 26 Jan 1986 & & 0 \\
\hline Vietnam & 30 Apr 1975 & & 0 \\
\hline Yemen & 15 Dec 1948 & 26 Sep 1962 & 0 \\
\hline Yemen-North/Arab Rep. & 23 May 1970 & 27 Apr 1994 & 0 \\
\hline Yemen-South/Peoples' Rep. & 25 Mar 1986 & & 0 \\
\hline Yemen & $10 \mathrm{Jul} 1994$ & & $2 *$ \\
\hline Yugoslavia-Bosnia & 14 Dec 1995 & & $5^{* * *}$ \\
\hline Yugoslavia-Croatia & 02 Jan 1992 & 22 Jan 1993 & 3 \\
\hline Yugoslavia-Croatia & 29 Mar 1994 & 04 Aug 1995 & 4 \\
\hline Yugoslavia-Croatia & 14 Dec 1995 & & $5^{* * *}$ \\
\hline Zimbabwe/Rhodesia & 21 Dec 1979 & 08 Mar 1983 & $3 *$ \\
\hline Zimbabwe/Rhodesia & 01 Aug 1984 & & 0 \\
\hline
\end{tabular}

\footnotetext{
Mission Type: *Non-UN mission **Both a UN and a non-UN mission (highest mission value noted)

$0=$ none

$2=$ observer mission

$3=$ traditional peacekeeping mission

$4=$ multidimensional peacekeeping mission

$5=$ enforcement mission
} 


\section{References}

Blechman, B., W. Durch, W. Eaton, and T. Stanley (1997) Effective Transitions to Sustainable Peace. Washington, DC: DFI International.

Box-Steffensmeier, J. M., And B. S. Jones (1997) Time Is of the Essence: Event History Models in Political Science. American Journal of Political Science 41(4):1414-61.

Box-Steffensmeier, J. M., D. Reiter, And C. Zorn (2003) Nonproportional Hazards and Event History Analysis in International Relations. Journal of Conflict Resolution 47(1):33-53.

Collier, P., and A. Hoeffler (1999) On Economic Causes of Civil War. World Bank Research Working Paper.

Collier, P., and A. Hoeffler (2000) Greed and Grievance in Civil War. World Bank Policy Research Working Paper 2355.

Collier, P., And A. Hoeffler (2002) On the Incidence of Civil War in Africa. Journal of Conflict Resolution 46(1):13-28.

Dawson, P. (1994) The Peacekeepers of Kashmir. London: Hurst \& Co.

Doyle, M. W. (1995) UN Peacekeeping in Cambodia: UNTAC's Civil Mandate, International Peace Academy Occasional Papers. Boulder, CO: Lynne Rienner.

Doyle, M. W., And N. Sambanis (2000) International Peacebuilding: A Theoretical and Quantitative Analysis. American Political Science Review 94(4):779-802.

Dubey, A. (2002) Domestic Institutions and the Duration of Civil War Settlements. Paper presented at the Annual Meeting of the International Studies Association, March 24-27, New Orleans.

Durch, W. J., ed. (1993) The Evolution of UN Peacekeeping. New York: St. Martin's Press.

Durch, W. J., ed. (1996) UN Peacekeeping, American Politics and the Uncivil Wars of the 1990s. New York: St. Martin's Press.

Elbadawi, I., ANd N. Sambanis (2000) External Interventions and the Duration of Civil Wars. World Bank Research Working Paper.

Elbadawi, I., AND N. Sambanis (2001) How Much War Will We See? Estimating the Incidence of Civil War in 161 Countries. World Bank Research Working Paper.

FEARON, J. D. (1995) Rationalist Explanations for War. International Organization 49(3):379-414.

Fearon, J. D. (2002) Why Do Some Civil Wars Last So Much Longer Than Others? World Bank Research Working Paper.

Fearon, J. D., And D. D. Laitin (2003) Ethnicity, Insurgency, and Civil War. American Political Science Review 97(1):75-90.

Fortna, V. P. (2004) Peace Time: Cease-Fire Agreements and the Durability of Peace. Princeton, NJ: Princeton University Press.

Gilligan, M., And S. J. Stedman (2001) Where Do the Peacekeepers Go? International Studies Review $\mathbf{5}(4): 37-54$.

Hampson, F. O. (1996) Nurturing Peace: Why Peace Settlements Succeed or Fail. Washington, DC: United States Institute of Peace Press.

Hartzell, C., M. Hoddie, And D. Rothchild (2001) Stabilizing the Peace After Civil War. International Organization 55(1):183-208.

Hensel, P. R. (1994) One Thing Leads to Another: Recurrent Militarized Disputes in Latin America, 1816-1986. Journal of Peace Research 31(3):281-97.

Hoddie, M., And C. Hartzell (2003) Managing Domestic Anarchy: Liberal Institutionalism and the Resolution of Civil Wars. Paper presented at the Annual Meeting of the International Studies Association, February 26-March 1, Portland, Oregon.

Holiday, D., And W. Stanley (1992) Building the Peace: Preliminary Lessons from El Salvador. Journal of International Affairs 46(2).

Howard, L. M. (2001) Learning to Keep the Peace? United Nations Multidimensional Peacekeeping in Civil Wars. Ph.D. diss., Political Science, University of California, Berkeley.

Kalyvas, S. N. (2001) "New" and “Old” Civil Wars: A Valid Distinction? World Politics 54(1):99-118.

Kaufmann, C. (1996) Possible and Impossible Solutions to Ethnic Civil Wars. International Security 20(4):136-75.

Keesing's Record of World Events. London: Longman.

Kozhemiakin, A. (1994) Outcomes of War and the Durability of Peace Settlements. Unpublished Paper.

Licklider, R. (1995) The Consequences of Negotiated Settlements in Civil Wars, 1945-1993. American Political Science Review 89(3):681-87.

LutTwak, E. N. (1999) Give War a Chance. Foreign Affairs 78(4):36-44. 
MAOZ, Z. (1984) Peace by Empire? Conflict Outcomes and International Stability, 1816-1976. Journal of Peace Research 21(3):227-41.

Mearsheimer, J. J., and R. A. Pape (1993) The Answer. The New Republic, June 14:22-29.

Soderbom, M., P. Collier, And A. Hoeffler (2002) On the Duration of Civil War. World Bank Research Working Paper.

Stinnett, D. M., And P. F. Diehl (2001) The Path(s) to Rivalry: Behavioral and Structural Explanations of Rivalry Development. Journal of Politics 63(3):717-40.

Tharoor, S. (1995/96) Should UN Peacekeeping Go "Back to Basics"? Survival 37(4):52-64.

TofT, M. D. (2003) Peace through Victory? Paper Presented at the Annual Meeting of the American Political Science Association, August 27-31, Philadelphia.

Walter, B. (2001) Committing to Peace: The Successful Settlement of Civil Wars. Princeton, NJ: Princeton University Press.

Walter, B. (2004) Does Conflict Beget Conflict? Explaining Recurring Civil War. Journal of Peace Research 41(3).

Werner, S. (1999) The Precarious Nature of Peace: Resolving the Issues, Enforcing the Settlement and Renegotiating the Terms. American Journal of Political Science 43(3):912-34. 